\title{
Yoga and Hypertension
}

\section{${ }^{1}$ Subhash Chandra Manchanda, ${ }^{2}$ Kushal Madan}

\section{ABSTRACT}

Hypertension is a major public health problem and is an important risk factor for stroke, coronary heart disease and renal failure. The blood pressure is not well controlled with drug therapy in large number of individuals, especially in the developing countries. There is a need for less expensive nonpharmacological alternative methods to control blood pressure. Yoga may be such cost-effective alternative. Several uncontrolled and randomized control trials have evaluated short- and long-term effects of yoga/meditation-based techniques in prehypertension and mild hypertension. Though, the results are mixed and there are several methodological limitations in reported studies, majority of studies demonstrate a modest decrease in both systolic and diastolic blood pressure. This modest decrease may significantly decrease the stroke mortality and coronary heart disease in general population. A recent scientific statement of American Heart Association also suggests that it is reasonable for all individuals with blood pressure levels more than 120/80 $\mathrm{mm} \mathrm{Hg}$ to consider alternative approaches like transcendental medication as adjunct method to lower blood pressure.

Keywords: Meditation, Prehypertension, Psychosocial stress, Yoga.

How to cite this article: Manchanda SC, Madan K. Yoga and Hypertension. Hypertens J 2015;1(1):28-33.

\section{Source of support: Nil}

Conflict of interest: None

\section{INTRODUCTION}

Hypertension (HTN) is a major public health issue worldwide, because of its high prevalence and concomitant increase in risk of disease. Currently, $26 \%$ of world population is estimated to have HTN which translates to over 1 billion people with this disorder. ${ }^{1}$ Hypertension is a predisposing risk factor for stroke, myocardial infarction, heart failure, arterial aneurysms and chronic renal failure. ${ }^{2}$ Blood pressure is well controlled in less than $50 \%$ of the individuals with HTN, especially in the low and middle income countries. ${ }^{3}$ Uncontrolled HTN is thought to be responsible for $62 \%$ of cerebrovascular diseases

\section{${ }^{1}$ Professor, ${ }^{2}$ Cardiac Rehabilitation Consultant \\ 1,2Department of Cardiology, Sir Ganga Ram Hospital, New} Delhi, India

Corresponding Author: Subhash Chandra Manchanda Professor, Department of Cardiology, Sir Ganga Ram Hospital, New Delhi, India, Phone: 9873695460 , e-mail: doctor manchanda@yahoo.com and $45 \%$ of ischemic heart disease events. According to International society of hypertension estimates, 370 billion US dollars were spent in the year 2001, because of nonoptimal blood pressure control accounting for $10 \%$ of all healthcare expenditures. ${ }^{4}$ The cost of drugs, side-effects and nonadherence with prescribed drug regimens, all contribute to the high rate of uncontrolled HTN. Alternately, less expensive nonpharmacological methods to control blood pressure that have no sideeffects of drugs, and which may convey the benefits of long-term adherence are much needed. Yoga may be one such alternative technique that may improve high blood pressure.

\section{WHAT IS YOGA?}

The word yoga comes from a Sanskrit word 'Yug' which means to join together. It connotes joining the mind with the body or lower human nature to the higher. ${ }^{5}$ Originating in India about 4,000 years ago, the practice of yoga is becoming increasingly popular globally. Even United Nations has realized its importance and declared 21st June as International day of Yoga. Yoga is an integrated system of self-culture, which aims at harmonious development of body and mind, and covers all aspects of human-life that lead to physical well-being, mental harmony culminating into positive thinking, happiness and peace. Yoga envisages health in totality on the principle of 'healthy mind in a healthy body'. Although there are many types of yoga, hatha yoga is most commonly practiced. Core components of hatha yoga include-stretching exercises and physical postures (asanas), breath control (pranayama) and concentration techniques (meditation); designed to promote physical, mental, emotional and spiritual well-being. Yoga is believed to help detoxify the body, mitigate chronic fatigue, enhance endurance and improve organ and immune functions. ${ }^{6}$ Beneficial effects of yoga have been reported in multiple chronic conditions includingdepression, stress, anxiety, menopausal symptoms, arthritis, low back pain, cancer, allergies, asthma, acid peptic disease, irritable bowel syndrome, migraine, metabolic syndrome, diabetes mellitus, cardiovascular diseases (CVD), etc. ${ }^{7-9}$ A large number of studies have evaluated the role of yoga in HTN and these are reviewed in this article. 
Yoga and Hypertension

\section{ROLE OF YOGA IN HYPERTENSION}

Several controlled and uncontrolled studies have demonstrated the short- and long-term usefulness of yoga in the treatment of hypertension. In earlier studies, involving the use of shavasana (corpse posture, a type of yogic activity for relaxation by auto suggestion), a significant reduction in blood pressure was noticed. ${ }^{10}$ In another prospective study conducted by Benson et al in 14 subjects with baseline systolic blood pressure (SBP) of 145.6 $\mathrm{mm} \mathrm{Hg}$ and diastolic blood pressure (DBP) of $91.9 \mathrm{~mm}$ $\mathrm{Hg}$, a transcendental meditation 30 minutes twice daily decreased the blood pressure to $135.5 / 87 \mathrm{~mm} \mathrm{Hg} .{ }^{11}$ One randomized controlled trial demonstrated that yoga is capable of producing the long-term beneficial effect in the treatment of HTN. ${ }^{12}$ In another randomized trial, yoga was found to be equally effective as antihypertensive pharmacotherapy over a 11 weeks period. ${ }^{13}$

A review of literature in 1987 analyzed 25 randomized controlled trials of stress management in mild HTN. ${ }^{14}$ There was an average reduction of $8.8 \mathrm{~mm} \mathrm{Hg} \mathrm{SBP} \mathrm{(control}$ $3.15 \mathrm{~mm} \mathrm{Hg}$ ) and $6.21 \mathrm{~mm} \mathrm{Hg}$ in DBP (control $3.05 \mathrm{~mm}$ $\mathrm{Hg}$ ). In another meta-analysis of 16 controlled comparative studies involving cognitive studies or placebo (pseudomeditation, sham bio-feedback or self-relaxation), the systolic BP was reduced by $2.8 \mathrm{~mm} \mathrm{Hg}$ (95\% CI 0.8-6.4) and diastolic by $1.3 \mathrm{~mm} \mathrm{Hg}$ (95\% CI 1.3-3.8). ${ }^{15}$ These changes were not statistically significant, but in several individuals the blood pressure was significantly lowered. However, many studies showing the benefit of yoga in HTN were not scientifically very sound because of small sample size, inconsistencies in baseline blood pressure and absence of adequate controls.

Recently, several controlled trials have evaluated the immediate and long-term effects of yoga practices in prehypertensives and mildly hypertensives (Table 1). Bhavnani et al observed that chandra nadi pranayama (left unilateral forced nostril breathing) had an immediate effect on lowering blood pressure in hypertensive patients. ${ }^{28}$ In a randomized control trial utilizing rigorous methodology comparing the effects of yoga with an active control on ambulatory blood pressure in individuals with prehypertension and stage 1 hypertension, Hagins et al observed a modest, but significant decrease in 24 hours diastolic, night diastolic and mean arterial pressure $(-3.93$, $-4.7,-4.23 \mathrm{~mm} \mathrm{Hg}$ respectively) as compared to controls. ${ }^{20}$ Similarly, other investigators utilizing different yoga practices have also observed a small but significant reduction of systolic and diastolic blood pressure, with a follow-up varying from 1 to 14 weeks (Table 1). However, some other have shown no benefit of yoga in decreasing blood pressure. One recent study reported that mind fullness based stress reduction (MBSR) did not lower ambulatory blood pressure by a statistically or clinically significant amount in stage one hypertensive patients, when compared with controls after 12 weeks. ${ }^{22}$

\section{RECENT STUDIES}

As most of the studies are small, numerous metaanalyses and reviews have been reported recently. These reviews have included studies of yoga vs no treatment, yoga us conventional therapy and yoga combined with conventional therapy vs conventional therapy. Ambulatory blood pressure has been utilized in some studies.

In an earlier review in 2007, 32 articles published from 1980 to 2007 were reviewed..$^{35}$ Reductions in blood pressure were noticed in 25 studies. One of the good metaanalysis in 2008, studying the effects of transcendental meditation (TM) on blood pressure, included nine well conducted randomized controlled trials. The TM when compared to control, was associated with reduction in SBP by $4.7 \mathrm{~mm} \mathrm{Hg}$ (CI 1.9-7.4) and DBP of $3.2 \mathrm{~mm} \mathrm{Hg}$ (CI 1.3-5.4), suggesting that regular practice of TM may have the potential to modestly reduce systolic and diastolic blood pressure. ${ }^{16}$

Okonta et al in 2012 analyzed 10 studies between 2006 and 2011, which included randomized control trials (RCTs), quasi experimental studies and pilot studies, and they observed that yoga reduced high blood pressure and also blood glucose, cholesterol levels and body weight. ${ }^{36}$ Hagins et al (2013) did a systemic review and meta-analysis of 17 studies and observed a modest but significant decrease in SBP $(-4.17 \mathrm{~mm} \mathrm{Hg})$ and DBP (-3.62 $\mathrm{mm} \mathrm{Hg}$ ). The subgroup analysis demonstrated that studies incorporating three basic elements of yoga (posture, meditation and breathing) showed a greater decrease in blood pressure. ${ }^{37}$ Wang et al in the same year, did a systematic review of six RCTs (involving 386 patients) and observed that there is encouraging evidence of yoga to lower systolic and diastolic blood pressure. ${ }^{38}$ However, because of low methodological quality of these trials a definite conclusion about the efficacy of yoga cannot be drawn. Tyagi and Cohen in 2014 did a systematic review of all published studies on yoga and HTN.$^{39}$ Their review included 39 cohort studies, 30 nonrandomized controlled trials, 48 RCTs and three case reports with duration ranging from 1 week to 4 years involving a total of 6693 subjects. Most studies reported that yoga effectively reduced blood pressure in both normotensive and hypertensive population. Posadzki et al (2014) also did a systematic review of 17 RCTs, out of which only two RCTs were of acceptable methodological quality. ${ }^{40}$ Eleven RCTs suggested that yoga leads to a greater reduction in SBP as compared to controls, whereas 8 RCTs showed a greater reduction in DBP. Five RCTs had 
Table 1: Recent trials of yoga and hypertension

\begin{tabular}{|c|c|c|c|c|c|}
\hline Author and year & Type of study & $\begin{array}{l}\text { No. of } \\
\text { subjects } \\
\text { enrolled }\end{array}$ & Intervention & Duration & Results \\
\hline $\begin{array}{l}\text { Mashyal et al } \\
(2014)\end{array}$ & Self-controlled & 32 & $\begin{array}{l}\text { Yoga and } \\
\text { Laghu shankha } \\
\text { prakshalana kriya }\end{array}$ & 1 week & $\begin{array}{l}\text { Reduction in BP, anxiety and } \\
\text { fatigue. Increase in comfort and } \\
\text { quality of sleep }\end{array}$ \\
\hline $\begin{array}{l}\text { Tolbaños et al } \\
(2014)\end{array}$ & $\begin{array}{l}\text { Randomized } \\
\text { control }\end{array}$ & 10 & $\begin{array}{l}\text { Integrative yoga } \\
\text { program }\end{array}$ & 3 months & $\begin{array}{l}\text { Reduction in systolic and diastolic } \\
\text { BP, anxiety and stress }\end{array}$ \\
\hline $\begin{array}{l}\text { Patil et al } \\
(2014)\end{array}$ & $\begin{array}{l}\text { Randomized } \\
\text { control }\end{array}$ & 57 & Yoga & 3 months & $\begin{array}{l}\text { Reduced BP and oxidative stress } \\
\text { (MDA level) and increase in } \\
\text { antioxidants (SOD, GSH, vit C) }\end{array}$ \\
\hline $\begin{array}{l}\text { Hagins et al } \\
(2014)\end{array}$ & $\begin{array}{l}\text { Randomized } \\
\text { control }\end{array}$ & 84 & Yoga & & $\begin{array}{l}\text { Significant and modest reduction } \\
\text { in } 24 \text { hours DBP and MBP as } \\
\text { measured by ABPM }\end{array}$ \\
\hline $\begin{array}{l}\text { Wolff et al } \\
(2013)\end{array}$ & Control & 83 & Yoga & 12 weeks & $\begin{array}{l}\text { Significant decrease in DBP with } \\
\text { yoga at home }\end{array}$ \\
\hline $\begin{array}{l}\text { Blom et al } \\
(2014)\end{array}$ & $\begin{array}{l}\text { Randomized } \\
\text { control }\end{array}$ & 101 & MBSR & 12 weeks & No effect on ambulatory BP \\
\hline $\begin{array}{l}\text { Adhana et al } \\
\text { (2013) }\end{array}$ & Cohort & 30 & Yogic breathing & 3 months & Significant fall in SBP and DBP \\
\hline $\begin{array}{l}\text { Bhavanani et al } \\
(2012)\end{array}$ & $\begin{array}{l}\text { Pretest and } \\
\text { post-test }\end{array}$ & 29 & Pranava pranayama & 5 minutes & Significant fall in SBP and heart rate \\
\hline $\begin{array}{l}\text { Mizuno et al } \\
(2013)\end{array}$ & Control & 33 & Yoga & & Significant fall in SBP and DBP \\
\hline $\begin{array}{l}\text { Dhameja et al } \\
(2013)\end{array}$ & $\begin{array}{l}\text { Randomized } \\
\text { control }\end{array}$ & 60 & Yoga & 42 days & $\begin{array}{l}\text { Significant fall in blood pressure } \\
\text { and oxidative stress }\end{array}$ \\
\hline $\begin{array}{l}\text { Bhavanani et al } \\
(2012)\end{array}$ & $\begin{array}{l}\text { Pretest and } \\
\text { post-test }\end{array}$ & 22 & $\begin{array}{l}\text { Chandra nadi } \\
\text { pranayama }\end{array}$ & 5 minutes & $\begin{array}{l}\text { Significant fall in SBP and } \\
\text { heart rate }\end{array}$ \\
\hline $\begin{array}{l}\text { Chung et al } \\
(2012)\end{array}$ & Cohort & 129 & Sahaja yoga & & $\begin{array}{l}\text { Significant fall in blood pressure } \\
\text { and anxiety }\end{array}$ \\
\hline $\begin{array}{l}\text { Agte et al } \\
(2011)\end{array}$ & Control & 52 & Sudarshan kriya & 2 months & $\begin{array}{l}\text { Significant fall in DBP and oxidative } \\
\text { stress and lipids }\end{array}$ \\
\hline $\begin{array}{l}\text { Subramanian et al } \\
\text { (2011) }\end{array}$ & $\begin{array}{l}\text { Randomized } \\
\text { control }\end{array}$ & 94 & $\begin{array}{l}\text { Yoga, exercise and } \\
\text { diet }\end{array}$ & 8 weeks & $\begin{array}{l}\text { Significant fall in blood pressure } \\
\text { (with yoga, exercise and reduced } \\
\text { salt intake) }\end{array}$ \\
\hline $\begin{array}{l}\text { Murthy et al } \\
(2011)\end{array}$ & $\begin{array}{l}\text { Pretest and } \\
\text { post-test }\end{array}$ & 104 & $\begin{array}{l}\text { Yoga and } \\
\text { naturopathy }\end{array}$ & 21 days & $\begin{array}{l}\text { Significant fall in SBP, DBP, body } \\
\text { weight and lipids }\end{array}$ \\
\hline $\begin{array}{l}\text { Cade et al } \\
(2010)\end{array}$ & $\begin{array}{l}\text { Randomized } \\
\text { control }\end{array}$ & $\begin{array}{l}60 \text { HIV } \\
\text { infected }\end{array}$ & Yoga & 20 weeks & Significant fall in SBP and DBP \\
\hline $\begin{array}{l}\text { Cohen et al } \\
(2011)\end{array}$ & $\begin{array}{l}\text { Randomized } \\
\text { control }\end{array}$ & 57 & lyengar yoga & 12 weeks & $\begin{array}{l}\text { Significant fall in ambulatory SBP } \\
\text { and DBP }\end{array}$ \\
\hline $\begin{array}{l}\text { Posadzki et al } \\
(2014)\end{array}$ & $\begin{array}{l}\text { Review of } \\
17 \text { RCT }\end{array}$ & & Yoga & & $\begin{array}{l}11 \mathrm{RCT} \text {-reduction in SBP } \\
8 \mathrm{RCT} \text {-reduction in DBP } \\
5 \mathrm{RCT} \text {-no effect on SBP } \\
8 \mathrm{RCT} \text {-no effect on DBP }\end{array}$ \\
\hline $\begin{array}{l}\text { Cramer et al } \\
(2014)\end{array}$ & $\begin{array}{l}\text { Review and meta- } \\
\text { analysis of } 7 \text { RCT }\end{array}$ & 452 & Yoga & & $\begin{array}{l}\text { Low-quality evidence that yoga } \\
\text { may be an adjunct in management } \\
\text { of HTN }\end{array}$ \\
\hline $\begin{array}{l}\text { Tyagi et al } \\
(2014)\end{array}$ & $\begin{array}{l}\text { Review of } 39 \text { cohort, } \\
30 \text { non-RCT, } 48 \text { RCT, } \\
3 \text { case reports }\end{array}$ & 6693 & Yoga & $\begin{array}{l}1 \text { week-4 } \\
\text { years }\end{array}$ & $\begin{array}{l}\text { BP reduced in both normotensive } \\
\text { and hypertensive subjects }\end{array}$ \\
\hline $\begin{array}{l}\text { Wang et al } \\
(2013)\end{array}$ & Review of 6 RCT & 386 & Yoga & Variable & Lower DBP and SBP \\
\hline $\begin{array}{l}\text { Hagins et al } \\
(2013)\end{array}$ & Review of 17 studies & & Yoga & & Significant fall in SBP and DBP \\
\hline $\begin{array}{l}\text { Okonta et al } \\
(2012)\end{array}$ & Review of 10 trials & & Yoga & & Significant fall in BP and glucose \\
\hline
\end{tabular}


Yoga and Hypertension

no effect on SBP as compared to dietary modification or physical exercise and eight RCTs showed no effect on DBP. They concluded that effectiveness of yoga as treatment of HTN appears encouraging but inconclusive. Further, more rigorous trials are warranted. Cramer et al recently reported a systematic review and meta-analysis of seven RCTs with a total of 452 patients. ${ }^{41}$ In comparison to usual care, very low quality evidence was found for systolic and diastolic blood pressure. Sub-group analysis revealed that blood pressure was reduced only in hypertensive patients and those who were taking antihypertensive medications. These reviews suggest that the effects of yoga on blood pressure are mixed, although the majority of studies show a small, but significant decrease of blood pressure. These reviews have commented that most of the studies have low methodological quality, and hence large randomized well controlled studies are needed for defining the exact role of yoga in HTN.

Recently, a scientific committee of American Heart Association (AHA) has reviewed extensively the role of several alternative approaches beyond medication and diet to control HTN. The scientific committee has concluded that transcedental meditation and bio-feedback approaches showed modest effect in reducing blood pressure (class IIB, level of evidence B). It was the consensus of the writing group, that it is reasonable for all individuals with blood pressure levels more than $120 / 80 \mathrm{~mm} \mathrm{Hg}$ to consider alternative approaches as adjunct methods to help lower blood pressure when clinically appropriate. ${ }^{42}$

\section{LIMITATIONS OF YOGA STUDIES}

Although yoga and meditation have been found to be useful in reducing blood pressure in several trials, yet there are several limitations of reported studies. Most of the studies have small sample size; many have absence of adequate controls and non-uniform methodologies. Meta-analysis and reviews have similar limitations. Large multicenter randomized studies are needed to define the exact role of yoga in HTN. However, yoga is a cost-effective simple technique without any side-effects, an excellent method to control stress and has several other cardiovascular benefits. It could play a primary or a complimentary role in the management of prehypertension/HTN.

\section{Other Benefits of Yoga on Cardiovascular System}

Several randomized clinical trials have shown that yoga is beneficial for control of risk factors of disease, like diabetes mellitus, obesity, smoking, inflammation and mental stress. ${ }^{9,43-45}$ Yoga has also been shown to cause regression of early and advanced atherosclerosis as
Flow Chart 1: Psychophysiology of yoga in hypertension and heart disease ${ }^{43}$

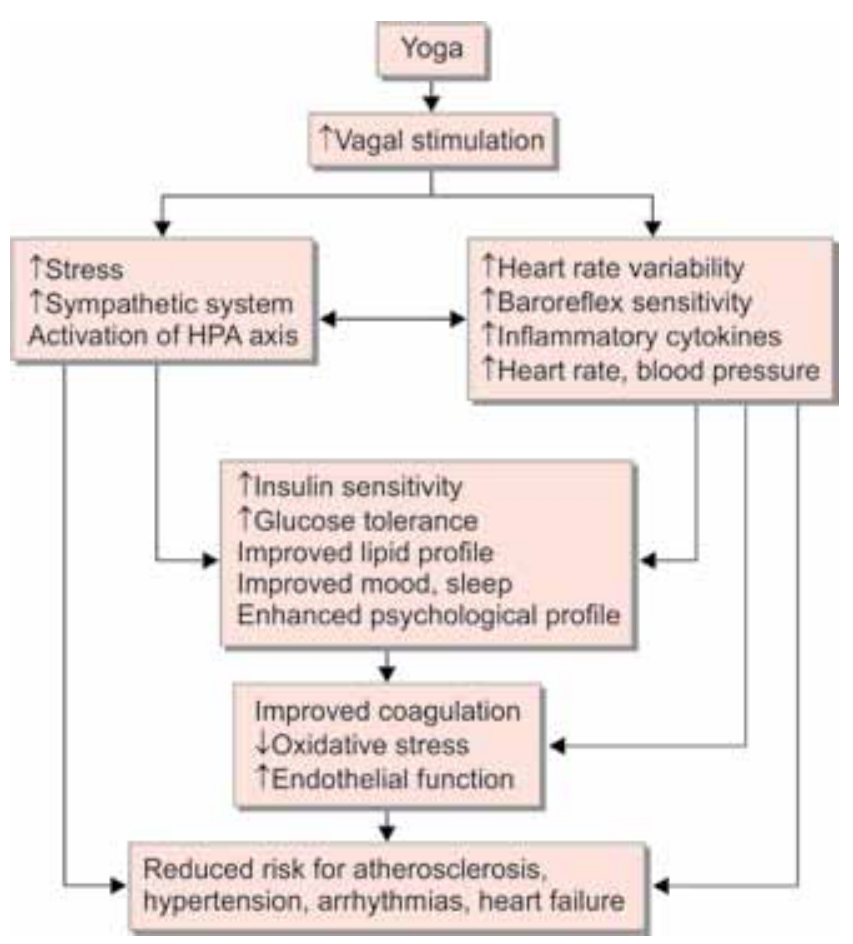

compared to controls. ${ }^{46-49}$ A secondary prevention trial utilizing TM has shown a reduction of $48 \%$ in cardiovascular mortality and myocardial infarction in patients with coronary heart disease, who were followed up for a mean of 5.4 years. ${ }^{50}$ Yoga may also be useful in cardiac arrhythmias and heart failure. ${ }^{51,52}$

\section{POSSIBLE MECHANISMS}

The exact mechanisms by which yoga may influence blood pressure are not fully understood. Innes et al suggested a model of hypothesized two pathways that may be responsible for decrease in blood pressure and risk of cardiovascular disease by yoga (Flow Chart 1). ${ }^{43}$ The physical practices of yoga may directly stimulate the vagus nerve, thus increasing its parasympathetic activity. Yoga may also reduce the feelings of stress and increase a sense of well being, reducing activation of sympathetic system and positively altering the neuroendocrine status and inflammatory responses. Some investigators have also demonstrated that reduction of blood pressure may be due to restoration of baroreceptor by yoga. ${ }^{53}$

\section{CONCLUSION}

Hypertension is widely prevalent throughout the world and is an important risk factor for stroke, coronary heart disease, heart and renal failure. However, blood pressure is not well controlled in large number of individuals, especially in the developing countries. Yoga appears to be a cost-effective alternative for controlling blood pressure. 
Several controlled and uncontrolled studies and metaanalyses have studied the short- and long-term effects of yoga on HTN. Although the methodological quality of many studies is poor and the results are mixed, most of the randomized controlled trials suggest a modest decrease in both systolic and diastolic blood pressure. This modest change in blood pressure may have a significant effect on reduction of stroke and coronary heart disease. It has been estimated that reducing SBP by just $3 \mathrm{~mm} \mathrm{Hg}$ in general population has the potential to reduce stroke mortality by $8 \%$ and coronary heart disease by $5 \% .{ }^{54}$ As most of the studies have several limitations, large, randomized, well designed trials are needed to define the exact role of yoga in HTN.

However, the recent scientific statement of AHA suggests that it is reasonable for all individuals with blood pressure levels more than $120 / 80 \mathrm{~mm} \mathrm{Hg}$ to consider alternative approaches like meditation as adjunct method to help lower blood pressure.

\section{REFERENCES}

1. Mendis, Shanthi, Puska, Pekka, Norving, Bo. Global atlas on cardiovascular disease prevention and control. Geneva: World Health Organization; 2011. p. 155.

2. Psaty BM, Furberg CD, Kuller LH, Cushman M, Savage PJ, Levine D, O'Leary DH, Bryan RN, Anderson M, Lumley T. Association between blood pressure level and the risk of myocardial infarction, stroke, and total mortality: the cardiovascular health study. Arch Intern Med 2001 May 14;161(9):1183-1192.

3. Chow CK, Teo KK, Rangarajan S, Islam S, Gupta R, Avezum A, Bahonar A, Chifamba J, Dagenais G, Diaz R, et al. Prevalence, awareness, treatment, and control of hypertension in rural and urban communities in high-, middle-, and low-income countries. JAMA 2013 Sep 4;310(9):959-968.

4. Gaziano TA, Bitton A, Anand S, Weinstein MC, International Society of Hypertension. The global cost of nonoptimal blood pressure. J Hypertens 2009 Jul;27(7):1472-1477.

5. Ananda, Sri. The Complete book of yoga: Harmony of body and mind. 1st ed. Delhi: Orient Paperbacks 1980. p. 175.

6. Raub JA. Psychophysiologic effects of hatha yoga on musculoskeletal and cardiopulmonary function: a literature review. J Altern Complement Med 2002;8(6):797-812.

7. Meditation practices for Health. State of the Research (2007) prepared for agency for Healthcare Research and Quantity; US Department of Health and Human Services. Available at: www.ahrg.gov.

8. Büssing A, Michalsen A, Khalsa SB, Telles S, Sherman KJ. Effects of yoga on mental and physical health: a short summary of reviews. Evid Based Complement Alternat Med 2012;2012:165410.

9. Manchanda SC, Madan K. Yoga and meditation in cardiovascular disease. Clin Res Cardiol 2014 Sep;103(9):675-680.

10. Datey KK, Deshmukh SN, Dalvi CP, Vinekar SL. 'Shavasan': A yogic exercise in the management of hypertension. Angiology 1969 Jun;20(6):325-333.
11. Benson H, Rosner BA, Marzetta BR, Klemchuk HM. Decreased blood pressure in pharmacologically treated hypertensive patients who regularly elicited the relaxation response. Lancet 1974 Feb 23;1(7852):289-291.

12. Patel C. 12 months follow-up of yoga and bio-feedback in the management of hypertension. Lancet 1975 Jan 11;1(7898): 62-64.

13. Murugesan R, Govindarajulu N, Bera TK. Effect of selected yogic practices on the management of hypertension. Ind J Physiol Pharmacol 2000 Apr;44(2):207-210.

14. Johnston DW. The behavioral control of high blood pressure. Curr Pychol 1987;6(2):99-114.

15. Eisenberg DM, Delbanco TL, Berkey CS, Kaptchuk TJ, Kupelnick B, Kuhl J, Chalmers TC. Cognitive behavioral techniques for hypertension: are they effective? Ann Intern Med 1993 Jun 15;118(12):964-972.

16. Anderson JW, Liu C, Kryscio RJ. Blood pressure response to transcendental meditation: a meta-analysis. Am J Hypertens 2008 Mar;21(3):310-316.

17. Mashyal $P$, Bhargav $H$, Raghuram N. Safety and usefulness of Laghu shankha prakshalana in patients with essential hypertension: a self-controlled clinical study. J Ayurveda Integr Med 2014 Oct-Dec;5(4):227-235.

18. Tolbaños Roche L, Mas Hesse B. Application of an integrative yoga therapy program in cases of essential arterial hypertension in public healthcare. Complement Ther Clin Pract 2014 Nov;20(4):285-290.

19. Patil SG, Dhanakshirur GB, Aithala MR, Naregal G, Das KK. Effect of yoga on oxidative stress in elderly with grade-I hypertension: a randomized controlled study. J Clin Diagn Res 2014 Jul;8(7):BC04-07.

20. Hagins M, Rundle A, Consedine NS, Khalsa SB. A randomized controlled trial comparing the effects of yoga with an active control on ambulatory blood pressure in individuals with pre-hypertension and stage 1 hypertension. J Clin Hypertens (Greenwich) 2014 Jan;16(1):54-62.

21. Wolff M, Sundquist K, Larsson Lönn S, Midlöv P. Impact of yoga on blood pressure and quality of life in patients with hypertension-a controlled trial in primary care, matched for systolic blood pressure. BMC Cardiovasc Disord 2013 Dec 7;13:111.

22. Blom $\mathrm{K}$, Baker B, How $\mathrm{M}$, Dai M, Irvine J, Abbey $\mathrm{S}$, Abramson BL, Myers MG, Kiss A, Perkins NJ, et al. Hypertension analysis of stress reduction using mindfulness meditation and yoga: results from the harmony randomized controlled trial. Am J Hypertens 2014 Jan;27(1):122-129.

23. Adhana R, Gupta R, Dvivedii J, Ahmad S. The influence of the 2:1 yogic breathing technique on essential hypertension. Indian J Physiol Pharmacol 2013 Jan-Mar;57(1):38-44.

24. Bhavanani AB, Madanmohan, Sanjay Z, Basavaraddi IV. Immediate cardiovascular effects of pranava pranayama in hypertensive patients. Ind J Physiol Pharmacol 2012 JulSep;56(3):273-278.

25. Cohen DL, Bowler A, Fisher SA, Norris A, Newberg A, RaoH, Bhavsar R, Detre JA, Tenhave T, Townsend RR. Lifestyle Modification in Blood Pressure Study II (LIMBS): study protocol of a randomized controlled trial assessing the efficacy of a 24 weeks structured yoga program vs lifestyle modification on blood pressure reduction. Contemp Clin Trials 2013 Sep;36(1):32-40. 
26. Mizuno J, Monteiro HL. An assessment of a sequence of yoga exercises to patients with arterial hypertension. J Bodyw Mov Ther 2013 Jan;17(1):35-41.

27. Dhameja K, Singh S, Mustafa MD, Singh KP, Banerjee BD, Agarwal M, Ahmed RS. Therapeutic effect of yoga in patients with hypertension with reference to GST gene polymorphism. J Altern Complement Med 2013 Mar;19(3):243-249.

28. Bhavanani AB, Madanmohan, Sanjay Z. Immediate effect of chandra nadi pranayama (left unilateral forced nostril breathing) on cardiovascular parameters in hypertensive patients. Int J Yoga 2012 Jul;5(2):108-111.

29. Chung SC, Brooks MM, Rai M, Balk JL, Rai S. Effect of Sahaja yoga meditation on quality of life, anxiety, and blood pressure control. J Altern Complement Med 2012 Jun;18(6): 589-596.

30. Agte VV, Jahagirdar MU, Tarwadi KV. The effects of Sudarshan Kriya Yoga on some physiological and biochemical parameters in mild hypertensive patients. Ind J Physiol Pharmacol 2011 Apr-Jun;55(2):183-187.

31. Subramanian $H$, Soudarssanane MB, Jayalakshmy $R$, Thiruselva kumar D, Navasakthi D, Sahai A, Saptharishi L. Non-pharmacological interventions in hypertension: a community-based cross-over randomized controlled trial. Ind J Community Med 2011 Jul;36(3):191-196.

32. Murthy SN, Rao NS, Nandkumar B, Kadam A. Role of naturopathy and yoga treatment in the management of hypertension. Complement Ther Clin Pract 2011 Feb;17(1):9-12.

33. Cade WT, Reeds DN, Mondy KE, Overton ET, Grassino J, Tucker S, Bopp C, Laciny E, Hubert S, Lassa-Claxton S, et al. Yoga lifestyle intervention reduces blood pressure in HIVinfected adults with cardiovascular disease risk factors. HIV Med 2010 Jul 1;11(6):379-388.

34. Cohen DL, Bloedon LT, Rothman RL, Farrar JT, Galantino ML, Volger S, Mayor C, Szapary PO, Townsend RR. Iyengar yoga versus enhanced usual care on blood pressure in patients with pre-hypertension to stage I hypertension: a randomized controlled trial. Evid Based Complement Alternat Med 2011;2011:546428.

35. Yang K. A review of yoga programs for four leading risk factors of chronic diseases. Evid Based Complement Alternat Med 2007 Dec;4(4):487-491.

36. Okonta NR. Does yoga therapy reduce blood pressure in patients with hypertension?: an integrative review. Holist Nurs Pract 2012 May-Jun;26(3):137-141.

37. Hagins M, States R, Selfe T, Innes K. Effectiveness of yoga for hypertension: systematic review and meta-analysis. Evid Based Complement Alternat Med 2013;2013:649836.

38. Wang J, Xiong X, Liu W. Yoga for essential hypertension: a systematic review. PLoS One 2013 Oct 4;8(10):e76357.

39. Tyagi A, Cohen M. Yoga and hypertension: a systematic review. Altern Ther Health Med 2014 Mar-Apr;20(2):32-59.

40. Posadzki P, Cramer H, Kuzdzal A, Lee MS, Ernst E. Yoga for hypertension: a systematic review of randomized clinical trials. Complement Ther Med 2014 Jun;22(3):511-522.

41. Cramer H, Haller H, Lauche R, Steckhan N, Michalsen A, Dobos G. A systematic review and meta-analysis of yoga for hypertension. Am J Hypertens 2014 Sep;27(9):1146-1151.
42. Brook RD, Appel LJ, Rubenfire M, Ogedegbe G, Bisognano JD, Elliott WJ, Fuchs FD, Hughes JW, Lackland DT, Staffileno BA, et al. Beyond medications and diet: alternative approaches to lowering blood pressure: a scientific statement from the american heart association. Hypertension 2013 Jun;61(6): 1360-1383.

43. Innes KE, Bourguignon C, Taylor AG. Risk indices associated with the insulin resistance syndrome, cardiovascular disease, and possible protection with yoga: a systematic review. J Am Board Fam Pract 2005;18(6):491-519.

44. Jayasinghe SR. Yoga in cardiac health (a review). Eur J Cardiovasc Prev Rehabil 2004;11:369-375.

45. Manchanda SC. Yoga-a promising technique to control cardiovascular disease. Ind Heart J 2014 Sep-Oct;66(5): 487-489.

46. Manchanda SC, Mehrotra UC, Makhija A, Mohanty A, Dhawan S, Sahwney JPS. Reversal of early atherosclerosis in metabolic syndrome by yoga: a randomized controlled trial. J Yoga Phys Ther 2013;3(1):132.

47. Ornish D, BrownSE, Scherwitz LW, Billings JH, ArmstrongWT, Ports TA, McLanahan SM, Kirkeeide RL, Brand RJ, Gould KL. Can lifestyle changes reverse coronary heart disease? The Lifestyle Heart Trial. Lancet 1990 Jul 21;336(8708):129-133.

48. Manchanda SC, Narang R, Reddy KS, Sachdeva U, Prabhakaran D, Dharmanand S, Rajani M, Bijlani R. Retardation of coronary atherosclerosis with yoga lifestyle intervention. J Assoc Physicians India 2000 Jul;48(7):687-694.

49. Gupta SK, Sawhney RC, Rai L, Chavan VD, Dani S, Arora RC, Selvamurthy W, Chopra HK, Nanda NC. Regression of coronary atherosclerosis through healthy lifestyle in coronary artery disease patients-Mount Abu Open Heart Trial. Ind Heart J 2011 Sep-Oct;63(5):461-469.

50. Schneider RH, Grim CE, Rainforth MV, Kotchen T, NidichSI, Gaylord-King C, Salerno JW, Kotchen JM, Alexander CN. Stress reduction in the secondary prevention of cardiovascular disease: randomized, controlled trial of transcendental meditation and health education in blacks. Circ Cardiovasc Qual Outcomes 2012;5(6):750-758.

51. Lakkireddy D, Atkins D, Pillarisetti J, Ryschon K, BommanaS, Drisko J, Vanga S, Dawn B. Effect of yoga on arrhythmia burden, anxiety, depression, and quality of life in paroxysmal atrial fibrillation: the YOGA my heart study. J Am Coll Cardiol 2013;61(11):1177-1182.

52. Krishna BH, Pal P, Pal G, Balachander J, Jayasettiaseelon E, Sreekanth Y, Sridhar M, Gaur G. A randomized controlled trial to study the effect of yoga therapy on cardiac function and $\mathrm{N}$ terminal Pro BNP in heart failure. Integr Med Insights 2014 Apr 1;9:1-6.

53. Selvamurthy W, Sridharan K, Ray US, Tiwary RS, Hegde KS, Radhakrishan U, Sinha KC. A new physiological approach to control essential hypertension. Ind J Physiol Pharmacol 1998 Apr;42(2):205-213.

54. Appel LJ. Lifestyle modification as a means to prevent and treat high blood pressure. J Am Soc Nephrol 2003 Jul;14(7 Suppl 2):S99-S102. 